\title{
浮遊砂混在平面 2 次元一般座標モデルと 石狩川模型実験の再現計算によるその検証 A STUDY ON THE NUMERICAL CALCULATION, REPLICATING THE MODEL EXPERIMENT OF THE ISHIKARI RIVER
}

\author{
伊東祐一郎 ${ }^{1} \cdot$ 清水康行 $^{2}$ \\ Yuichiro ITO and Yasuyuki SHIMIZU \\ 1 学生員 北海道大学大学院工学研究科 ( $\bar{T} 060-0813$ 札幌市北区北 13 条西 8 丁目) \\ 2 正会員 工博 北海道大学大学院工学研究科助教授 ( $\bar{T} 060-0813$ 札幌市北区北 13 条西 8 丁目)
}

It is important to estimate quantitatively suspended load, because the suspended load bring about a lot of problems, that is, sedimentation in reservoir, the drying wetland due to sedimentation of suspended load, and aggradation of the river mouth in river engineering, and affect riparian vegetation distribution and aquatic habitat in environmental engineering. In this study, a 2-D numerical model is presented to calculate the bed change considering the suspended load. The calculation for water flow, bed load and suspended load, and channel change was conducted in a generalized coordinate system. CIP method was used to calculated flow, and sediment transport equation in streamline and transverse wise considering secondary flow was used to compute bed change. This model is verified with model experiments on the downstream of the Ishikari river, which was conducted by CERI in 1984, and shows its applicability.

Key words: suspended load, bed load, CIP method, Ishikari river, model experiment.

\section{1.はじめに}

水の流れによって河床を構成する砂礫が移動する場 合に，その移動形式は大別して掃流と浮遊の 2 つがあ る. 掃流砂は砂碟が流水の流れ方向の抵抗力によって 河床のごく近くを移動する流砂であり, 浮遊砂は乱流 拡散現象によって上方に巻き上げられ，流路断面内を 流水とともに輸送される形式の流砂である. 浮遊砂を 含む流れは，例えばダム貯水池の堆砂や湿原の土砂堆 積による乾燥化, また砂州の形成による河口部の閉塞 など河床変動に大きな影響を与え, 実際上, 非常に重 要な問題である.さらに, 河口部の閉塞などは砂州の 生成・消滅過程が平面的な流況に大きく影響を受けて おり，そのメカニズム解明のためにも 2 次元以上の計 算モデルの発達が急務である. 図-1 は北海道尻別川で 問題となっている河口閉塞の様子である.

また，河川工学上の諸問題は複雑な境界を有するこ とが多い. 本研究もこういった観点から基本となる計 算千デルには境界に計算格子を適合させることが可能 な，平面 2 次元の一般座標系モデルを選択した。掃流 砂のみのモデルは多くの研究がなされており, その発 達はめざましいものがある. しかし, 浮遊砂に関する 諸問題は，複雑，かつ広範多岐にわたるため，未解明 の問題も多く残されているのが現状である.

本研究は, 平面 2 次元一般座標においても浮遊砂を 取り扱えるモデルの構築を目的としている。 まず Sinegenerated Curveの蛇行水路で試行計算を行い, モデル の特性の把握に努めた。 そして，模型実験の再現計算 によってその妥当性を検証した。この模型実験は昭和
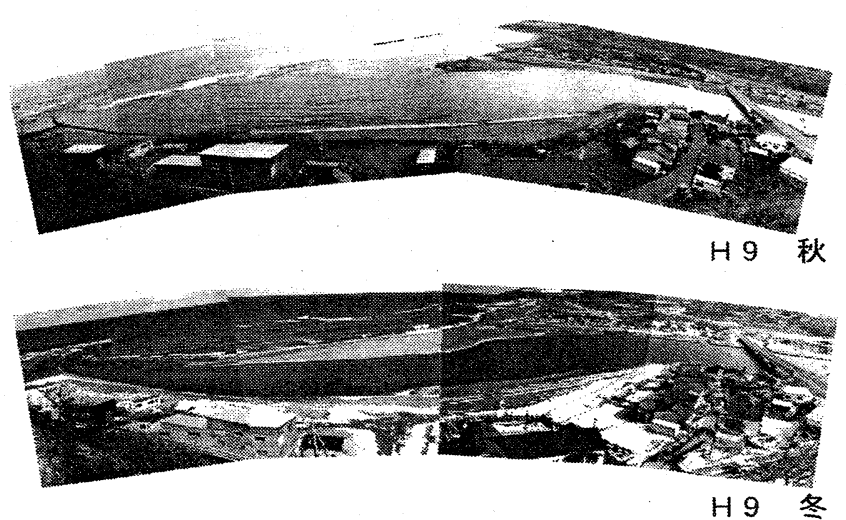

図 1: 河口部の閉塞 : 尻別川

59 年度に北海道開発局において行われた ${ }^{8), 9)}$ 石狩川下 流域を対象としたものである。この模型実験では, 浮 遊砂の発生を促進する目的で, 河床材料には比重の小 さい石炭紛が用いられている.

河床変動計算での浮遊砂の輸送については, 流れ場 を解く場合と同様，浮遊砂輸送に関する基礎式を NonAdvection Phase (非移流項) と Advection Phase（移 流項）に分離し, Advection Phaseには保存性に優れた CIP 法を用いて計算した。この手順は流れ場と同様の 計算手法が利用可能であるため, 計算プログラム作成 上も非常に有益である.

\section{2. 流れの基礎式}


流れの計算は以下に示す, 連続式と運動方程式 $(\xi, \eta$ 方向）による．座標系は一般座標系である.

$$
\begin{gathered}
\frac{\partial}{\partial t}\left(\frac{h}{J}\right)+\frac{\partial}{\partial \xi}\left(\frac{h u^{\xi}}{J}\right)+\frac{\partial}{\partial \eta}\left(\frac{h u^{\eta}}{J}\right)=0 \\
\frac{\partial u^{\xi}}{\partial t}+u^{\xi} \frac{\partial u^{\xi}}{\partial \xi}+u^{\eta} \frac{\partial u^{\xi}}{\partial \eta}+\alpha_{1} u^{\xi} u^{\xi}+\alpha_{2} u^{\xi} u^{\eta}+\alpha_{3} u^{\eta} u^{\eta} \\
=-g\left[\left(\xi_{x}^{2}+\xi_{y}^{2}\right) \frac{\partial H}{\partial \xi}+\left(\xi_{x} \eta_{x}+\xi_{y} \eta_{y}\right) \frac{\partial H}{\partial \eta}\right] \\
-\frac{C_{d} u^{\xi}}{J} \sqrt{\left(\eta_{y} u^{\xi}-\xi_{y} u^{\eta}\right)^{2}+\left(-\eta_{x} u^{\xi}+\xi_{x} u^{\eta}\right)^{2}}+D^{\xi}
\end{gathered}
$$

$$
\begin{aligned}
\frac{\partial u^{\eta}}{\partial t} & +u^{\xi} \frac{\partial u^{\eta}}{\partial \xi}+u^{\eta} \frac{\partial u^{\eta}}{\partial \eta}+\alpha_{4} u^{\xi} u^{\xi}+\alpha_{5} u^{\xi} u^{\eta}+\alpha_{6} u^{\eta} u^{\eta} \\
= & -g\left[\left(\eta_{x} \xi_{x}+\eta_{y} \xi_{y}\right) \frac{\partial H}{\partial \xi}+\left(\xi_{x}^{2}+\xi_{y}^{2}\right) \frac{\partial H}{\partial \eta}\right] \\
& -\frac{C_{d} u^{\eta}}{J} \sqrt{\left(\eta_{y} u^{\xi}-\xi_{y} u^{\eta}\right)^{2}+\left(-\eta_{x} u^{\xi}+\xi_{x} u^{\eta}\right)^{2}}+D^{\eta}
\end{aligned}
$$

ただし，

$$
\begin{aligned}
& \alpha_{1}=\xi_{x} \frac{\partial^{2} x}{\partial \xi^{2}}+\xi_{y} \frac{\partial^{2} y}{\partial \xi^{2}}, \alpha_{2}=2\left(\xi_{x} \frac{\partial_{x}^{2}}{\partial \xi \partial \eta}+\xi_{y} \frac{\partial_{y}^{2}}{\partial \xi \partial \eta}\right) \\
& \alpha_{3}=\xi_{x} \frac{\partial^{2} x}{\partial \eta^{2}}+\xi_{y} \frac{\partial^{2} y}{\partial \eta^{2}}, \alpha_{4}=\eta_{x} \frac{\partial^{2} x}{\partial \xi^{2}}+\eta_{y} \frac{\partial^{2} y}{\partial \xi^{2}} \\
& \alpha_{5}=2\left(\eta_{x} \frac{\partial^{2} x}{\partial \xi \partial \eta}+\eta_{y} \frac{\partial^{2} y}{\partial \xi \partial \eta}\right), \alpha_{6}=\eta_{x} \frac{\partial^{2} x}{\partial \eta^{2}}+\eta_{y} \frac{\partial^{2} y}{\partial \eta^{2}}
\end{aligned}
$$

ここで, $a_{b}$ は $\partial a / \partial b$ であることを示し,$t$ は時間, $h$ は 水深, $x, y$ は直交座標軸, $\xi, \eta$ は一般座標軸, $u^{\xi}, u^{\eta}$ は $\xi, \eta$ 方向流速の反変成分, $J$ は座標変換のヤコビア ン, $H$ は水位である， $D^{\xi}, D^{\eta}$ は粘性項を表す，紙面 の都合上，ここでは詳述しない．また，反変成分およ びヤコビアンの定義は以下に従う。

$$
\begin{gathered}
u^{\xi}=\left(\xi_{x} u+\xi_{y} v\right) / J, \quad u^{\eta}=\left(\eta_{x} u+\eta_{y} v\right) / J \\
J=\xi_{x} \eta_{y}-\xi_{y} \eta_{x}=\frac{1}{x_{\xi} y_{\eta}-x_{\eta} y_{\xi}}
\end{gathered}
$$

\section{3.浮遊砂輸送に関する基礎式（水深平均流）}

一般座標系における浮遊砂輸送の連続式は次式に示 される。

$$
\begin{aligned}
\frac{\partial}{\partial t}\left(\frac{\bar{c} h}{J}\right)+\frac{\partial}{\partial \xi}\left(\frac{u^{\xi} \bar{c} h}{J}\right) & +\frac{\partial}{\partial \eta}\left(\frac{u^{\eta} \bar{c} h}{J}\right) \\
& =\left(\frac{q_{s u}}{J}-\frac{w_{f} c_{b}}{J}\right)
\end{aligned}
$$

ここで, $\bar{c}$ は水深平均の浮遊砂濃度, $q_{s u}$ は河床からの 浮遊砂の浮上量, $w_{f}$ は砂粒の沈降速度, $c_{b}$ は河床近傍 での浮遊砂濃度である．拡散項については簡単のため, 省略して記述した.ここで，(1) 式，すなわち流れの連 続式を用いて上式を展開すると，次式のようになる.

$$
\frac{\partial \bar{c}}{\partial t}+u^{\xi} \frac{\partial \bar{c}}{\partial \xi}+u^{\eta} \frac{\partial \bar{c}}{\partial \eta}=\left(q_{s u}-w_{f} c_{b}\right) / h
$$

さらに，数值的に解きやすくするために，上式を Advection Phase (移流項) と Non-Advection Phase（非 移流項) に分ける (分離解法). Advection Phase につ いては CIP 法を用いて解く.この手法は流れの計算と 同様の手順をとるので，計算プログラム作成上も非常 に有益である。

$$
\frac{\partial \bar{c}}{\partial t}+u^{\xi} \frac{\partial \bar{c}}{\partial \xi}+u^{\eta} \frac{\partial \bar{c}}{\partial \eta}=0 \quad: \text { AdvectionPhase }
$$

$$
\frac{\partial \bar{c}}{\partial t}=\left(q_{s u}-w_{f} c_{b}\right) / h \quad: \text { NonAdvectionPhase }
$$

(8) 式中の水深平均浮遊砂濃度 $\bar{c}$ と河床近傍の浮遊砂 濃度 $c_{b}$ の関係は水深方向の濃度分布式より求められる が，ここでは以下に示す指数型の分布式を採用するも のとする.

$$
c=c_{b} \exp (-\beta \zeta)
$$

ただし, $\beta=w_{f} h / \epsilon, \zeta=z / h, z$ は河床からの距離, $\epsilon$ は水深平均の拡散係数 $\left(=\kappa u_{*} h / 6\right), \kappa$ はカルマン定数 $(=0.4), c$ は河床から $z$ の距離における浮遊砂の濃度 である。

水深平均の浮遊砂濃度 $\bar{c}$ は式 (11) を河床から水面まで 積分することにより次式となる.

$$
\bar{c}=\frac{1}{h} \int_{0}^{1} c d \zeta=\frac{c_{b}}{\beta}(1-\exp (-\beta))
$$

上式が (8) 式中の水深平均浮遊砂濃度 $\bar{c}$ と河床近傍の浮 遊砂濃度 $c_{b}$ の関係である.

(8) 式中の浮遊砂の単位面積あたりの浮上量 $q_{s u}$ の算定 には, 次式の板倉・岸の式 ${ }^{1)}$ を用いる.

$$
\begin{gathered}
q_{s u}=K\left(\alpha_{*} \frac{\rho_{s}-\rho}{\rho_{s}} \frac{g d}{u_{*}} \Omega-w_{f}\right) \\
\Omega=\frac{\tau_{*}}{B_{*}} \frac{\int_{a^{\prime}}^{\infty} \xi \frac{1}{\sqrt{\pi}} \exp \left(-\xi^{2}\right) d \xi}{\int_{a^{\prime}}^{\infty} \frac{1}{\sqrt{\pi}} \exp \left(-\xi^{2}\right) d \xi}+\frac{\tau_{*}}{B_{*} \eta_{0}}-1
\end{gathered}
$$

また, $a^{\prime}=B_{*} / \tau_{*}-1 / \eta_{0}, \quad \eta_{0}=0.5, \quad \alpha_{*}=0.14, \quad K=$ $0.008, \rho_{s}$ は浮遊粒子の密度, $\rho$ は水の密度である. $B_{*}$ は 揚力算定の際の速度に摩擦速度 $u_{*}$ を適用するための換 算係数であり，均一粒径を考えているので， $B_{*}=0.143$ である。

石炭紛は粒径が小さくなると薄片状の形状になり，沈 降速度の評価が難しいとされる。しかし，本研究にお いては簡易的に，砂粒の沈降速度を次式の Rubey の実 験式を用いて計算した。

$$
\frac{w_{f}}{\sqrt{s g d}}=\sqrt{\frac{2}{3}+\frac{36 \nu^{2}}{s g d^{3}}}-\sqrt{\frac{36 \nu^{2}}{s g d^{3}}}
$$


ここで, $\nu$ は水の動粘性係数 $\left(=0.01 \mathrm{~cm}^{2} / \mathrm{s}\right), s$ は砂粒 の水中比重 $(=1.65$, ただし石炭紛の場合は 0.436 とな る ), $d$ は砂粒の粒径 $(\mathrm{cm}), g$ は重力加速度である.

\section{4 . 河床変動に関する基礎式}

平面 2 次元一般座標系における掃流砂・浮遊砂を含 む河床変動の連続式を次式に示す。

$$
\begin{aligned}
\frac{\partial}{\partial t}\left(\frac{z_{b}}{J}\right)+\frac{1}{1-\lambda}\left[\frac{\partial}{\partial \xi}\left(\frac{q^{\xi}}{J}\right)+\frac{\partial}{\partial \eta}\left(\frac{q^{\eta}}{J}\right)\right. \\
\left.+\left(\frac{q_{s u}}{J}-\frac{w_{f} c_{b}}{J}\right)\right]=0
\end{aligned}
$$

ただし, $z_{b}$ は河床の標高, $\lambda$ は空隙率, $q^{\xi}, q^{\eta}$ は $\xi, \eta$ 方向の単位幅掃流砂量の反変成分である. 単位幅流砂 量の反変成分も実際の単位幅流砂量の次元である [長さ $2 /$ 時間] で表すためには, 以下の変換が必要となる.

$$
\widetilde{q^{\xi}}=\frac{q^{\xi}}{\xi_{r}} \quad, \quad \widetilde{q^{\eta}}=\frac{q^{\eta}}{\eta_{r}}
$$

ここで, $\widetilde{q^{\xi}}, \widetilde{q^{\eta}}$ は $\xi, \eta$ 方向の掃流砂量である.また, $\xi_{r}, \eta_{r}$ は局所的な格子サイズ $\Delta \widetilde{\xi}, \Delta \widetilde{\eta}$ と，一般座標上の 格子サイズ $\Delta \xi, \Delta \eta$ との比であり, 次式で定義される.

$$
\frac{\Delta \xi}{\Delta \widetilde{\xi}}=\xi_{r}, \quad \frac{\Delta \eta}{\Delta \widetilde{\eta}}=\eta_{r}
$$

$\xi, \eta$ 方向の掃流砂量 $\widetilde{q^{\xi}}, \widetilde{q^{\eta}}$ は渡邊ら ${ }^{3)}$ の方法に準拠 し, 次式で与えられる.

$$
\begin{gathered}
\widetilde{q^{\xi}}=q_{b}\left[\frac{\widetilde{u_{b}^{\xi}}}{V_{b}}-\gamma\left(\frac{\partial z_{b}}{\partial \widetilde{\xi}}+\cos \theta \frac{\partial z_{b}}{\partial \widetilde{\eta}}\right)\right] \\
\widetilde{q^{\eta}}=q_{b}\left[\frac{\widetilde{u_{b}^{\eta}}}{V_{b}}-\gamma\left(\frac{\partial z_{b}}{\partial \widetilde{\eta}}+\cos \theta \frac{\partial z_{b}}{\partial \widetilde{\xi}}\right)\right]
\end{gathered}
$$

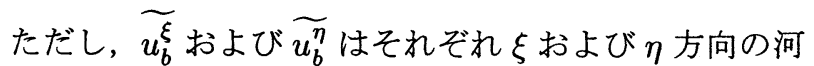
床近傍の流速, $q_{b}$ は全掃流砂量, $V_{b}$ は河床近傍の合成 流速, $\theta$ は $\xi$ 軸と $\eta$ 軸のなす角度である. $\gamma$ は斜面勾配 による流砂の補正係数であり，長谷川 ${ }^{5)}$ によれば次式 で与えられる。

$$
\gamma=\sqrt{\frac{\tau_{* c}}{\mu_{s} \mu_{k} \tau_{*}}}
$$

ただし， $\mu_{s}$ および $\mu_{k}$ は河床材料の静止摩擦保数およ び動摩擦係数である. (一般的な值として $\mu_{s} \mu_{k}=0.5$ ). 全掃流砂量 $q_{b}$ は次の芦田・道上の式 ${ }^{2)}$ で求める.

$$
q_{b}=17 \tau_{*}^{3 / 2}\left(1-\frac{\tau_{* c}}{\tau_{*}}\right)\left(1-\frac{u_{* c}}{u_{*}}\right) \sqrt{s g d^{3}}
$$

ここで, $s$. は砂粒の水中比重, $g$ は重力加速度, $d$ は河 床材料の粒径である.

\section{5. 河床近傍の流速（2 次流の取り扱い）}

水深平均流の流れに沿って, 水哚平均流速と河床近傍 の流速の関係を次式のような単純な関係式で仮定する.

$$
\widetilde{u_{b}^{s}}=\beta V
$$

ただし， $\widetilde{u_{b}^{s}}$ は水墚平均流の流線（以下単純に流線と呼

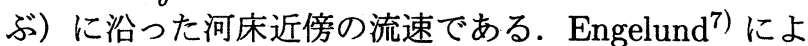
れば，水深方向の流速分布に放物線分布を用いた場合， $\beta$ は次式となる.

$$
\beta=3(1-\sigma)(3-\sigma), \quad \sigma=\frac{3}{\phi_{0} \kappa+1}
$$

ただし， $\phi_{0}$ は流速係数 $\left(=V / u_{*}\right), \kappa$ はカルマン定数 (=0.4)である.

一般に, 流線が曲がっている場合には 2 次流（螺旋 流）が発生する. ここでは, この 2 次流による河床近 傍の流速の算定に次式を用いる.

$$
\widetilde{u_{b}^{n}}=\widetilde{u_{b}^{s}} N_{*} \frac{h}{r_{s}}
$$

ただし， $\widetilde{u_{b}^{n}}$ は流線の方向に直交する方向（流線方向か ら反時計回りに 90 度の方向）の河床近傍の流速， $r_{s}$ は 流線の曲率半径, $N_{*}$ は定数 $\left(=7\right.$,Engelund $\left.{ }^{7)}\right)$ である. (23) 式および (25) 式より (19) 式および (20) 式中の $V_{b}$ は,

$$
V_{b}=\sqrt{{\widetilde{u_{b}^{s}}}^{2}+\widetilde{u_{b}^{n}}} \approx \widetilde{u_{b}^{s}}
$$

となる.なお上式の近似は，一般に $\widetilde{u_{b}^{n}}$ は $\widetilde{u_{b}^{s}}$ より1オ一 ダー小さい值となるためである.

(19) 式および (20) 式中, $\xi, \eta$ 方向の河床近傍流速 $\widetilde{u_{b}^{\xi}}$, $\underset{b}{\widetilde{n}}$ は, 流線方向の河床近傍流速 $\widetilde{u_{b}^{s}}$, 流線に直交する方 向の河床近傍流速 $\widetilde{u_{b}^{n}}$ を直交座標系に変換したのち, 一 般座標系に変換して求めるという手順をとる.

\section{6. 試行計算（Sine-generated Curve）}

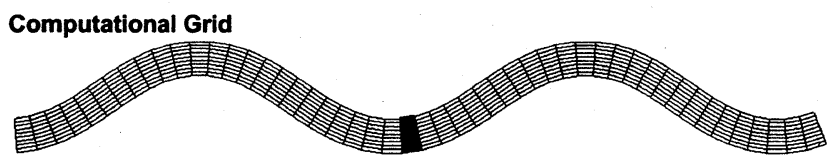

図 2: 計算格子

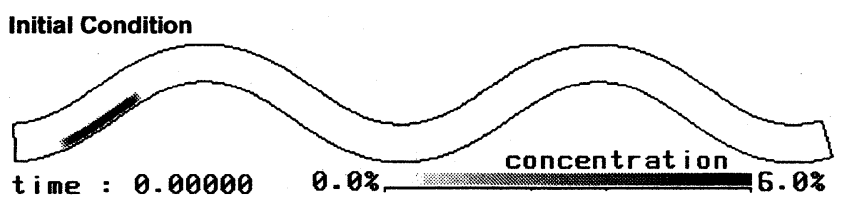

図 3: 初期条件（濃度分布）

図-4〜図-6 にモデル構築の基本段階で行った試行 計算の結果を示す.図-2 に示すような sine-generated curve の蛇行水路に初期条件図-3 として任意の濃度分 布を与えて，それが移流・拡散する様子を示した。図-4 ～図-6 は通水開始から 67 秒経過時点での濃度分布を表 す. 周期境界条件であるので，これは 21 波長分の湾曲 水路を流下したことになる.

ここでの濃度は河床との交換が行われないので, 浮遊 砂濃度というよりは，任意の物質の濃度輸送を表現し ている. 蛇行水路は流路幅: $0.2 m$, 蛇行波長 $: 2.2 m$, 起 点蛇行角 : $35^{\circ}$ ，河床勾配 : $1 / 111$ である。計算格子は 流下方向に 1 波長あたり 24 分割, 横断方向に 20 分割 


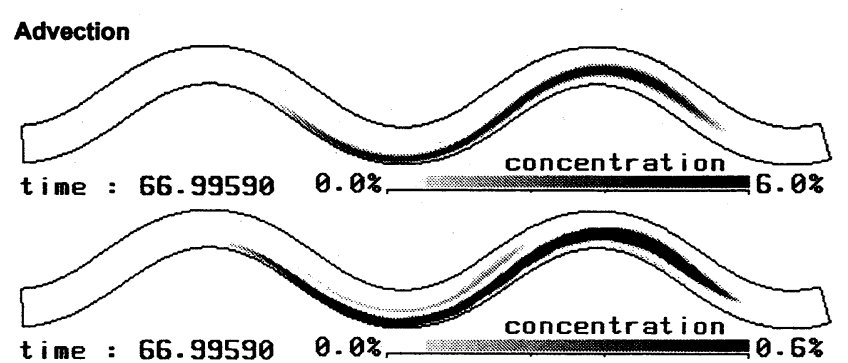

図 4: 濃度輸送 : 移流のみ

した. 図-2 は横断方向の計算格子を半数に間引いて表 示してある。また，上・下流端における境界条件は周 期境界条件である。すなわち下流端の水理量を最上流 端に与え, 上流端の水理量を最下流端に与えた.

主要な水理条件を以下に示す. 流量: $0.0026 \mathrm{~m}^{3} / \mathrm{s}$, 河 床材料の粒径 : $0.2 \mathrm{~mm}$, 砂粒子の水中比重 : 1.65 であ る.ここでは, 流れが掃流砂・浮遊砂の混在領域に入る ように, これらの值を選択した。図-4, 図-5 は移流 . 拡散ともにそれぞれの特徴をよく再現しているといえ よう.

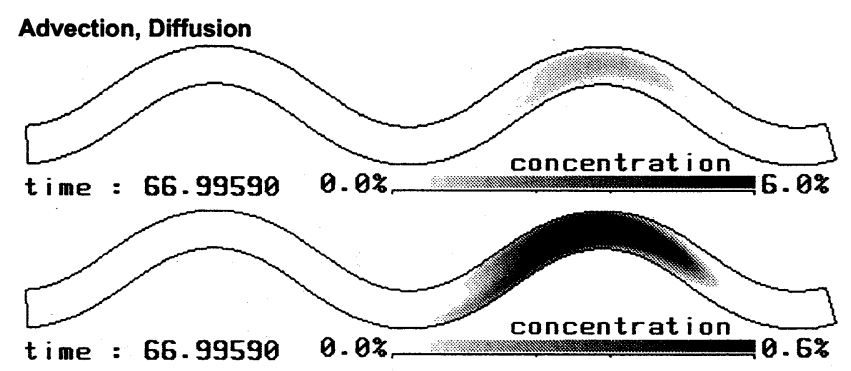

図 5: 濃度輸送 : 移流/拡散

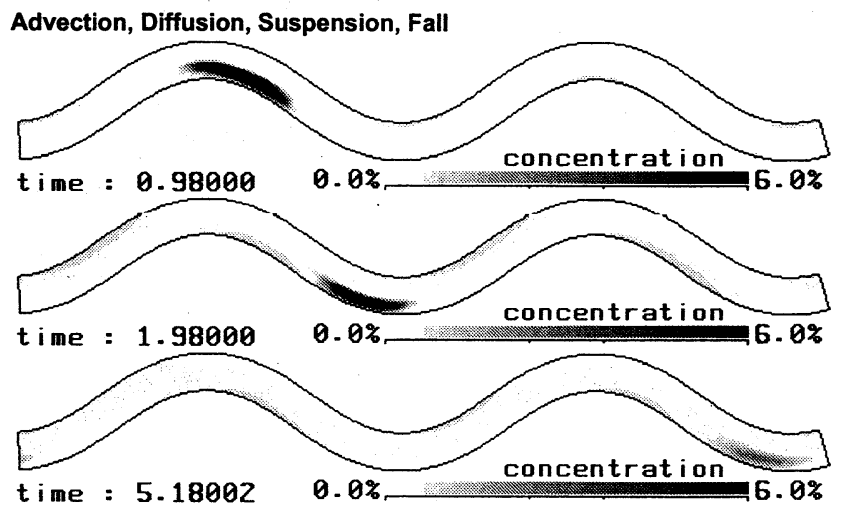

図 6: 濃度輸送：移流/拡散/浮上/沈降

次に，図-6に濃度の平面的な輸送とともに，鉛直方 向での濃度輸送を考慮した計算結果を示す。つまり, 濃 度の計算に，(8) 式に示す砂粒の浮上・沈降を表現する 非移流項を加えることにより, 濃度が浮遊砂濃度とし ての意味を持つ. 任意に与えた濃度が移流・拡散する とともに, 河床から砂粒の巻き上げが生じ, 流路全体 にわたって濃度が増大している．最終的にはある一定 濃度で平衡状態に達する。

そして，この浮遊砂濃度を(16) 式により, 河床との 交換に結び付け, 河床変動計算を行った。地形, 計算条 件は濃度輸送の計算と同様である。

まず，図-7 は掃流砂のみの河床変動計算結果であり， 初期河床からの変動量を表す. 河床の変動は通水開始か ら 100 秒経過した時点で開始している. また, 図-1の

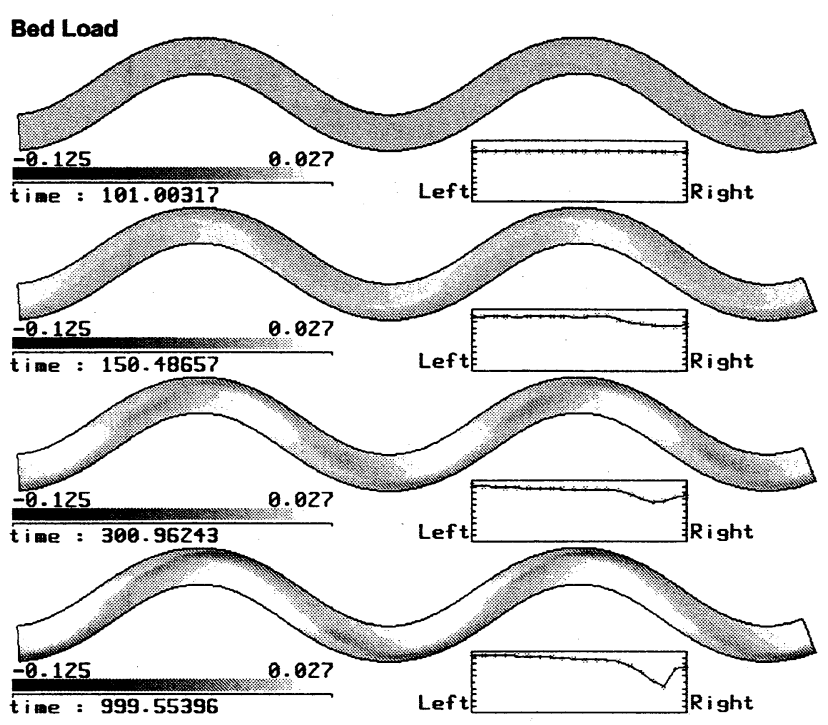

図 7: 河床変動計算 掃流砂のみ

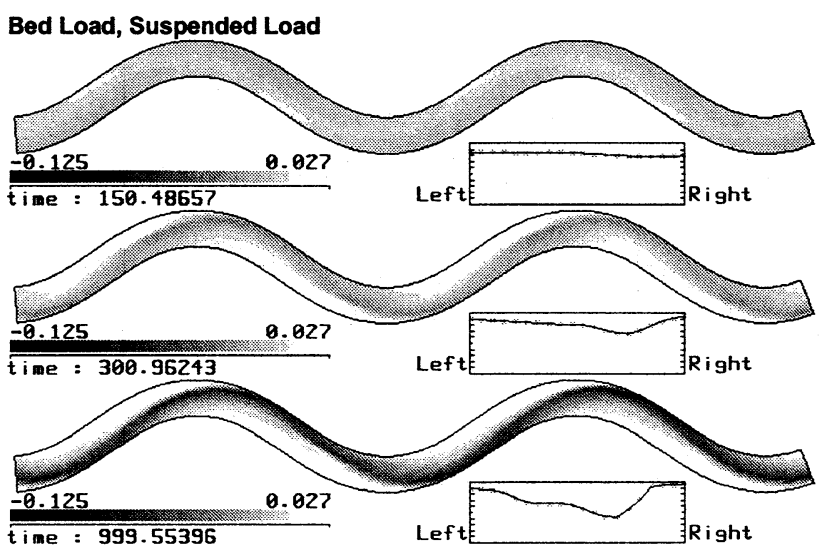

図 8: 河床変動計算 掃流砂/浮遊砂

計算格子図の黒く叙りつぶした地点における横断図も付 記してある. 横断図の鉛直軸は河床コンター図と同様に 初期河床からの変動量を表し，そのスケールは- $0.125 m$ 〜 0.027m である. 図-8, 図-9 は同様に，それぞれ，掃 流砂・浮遊砂混合モデル，浮遊砂のみのモデルによる河 床変動計算結果である。これらによると掃流砂のみの モデルと比べ, 浮遊砂混在モデルは湾曲部内岸側の砂 州がより細長く，滑らかな形状で形成されている。 ま た，横断図から読み取れるように，混在モデルの方が 最大洗掘深が大きく計算されており，その位置も，よ り流路中心に近いことがわかる.ただし,砂州が形成さ れるタイミングは掃流砂のみのモデルの方が早い.

図-9 は浮遊砂のみのモデルの計算結果である. 他の 2 つと決定的に異なるのは，基本的に流速の早く成る 所で澪筋状に洗掘されてしまい, 結果として湾曲部の 内岸側で侵食し，外岸側で堆積傾向にあることである. 掃流砂を含むモデルは全くその逆である.これはおそら く，2次流補正の有無によるものと思われる．掃流砂の 場合は 5 章に前述のとおり, 水深平均の流線に直交す る方向での掃流砂を考えることにより，2 次流補正を 行っている.すなわち, 流路の湾曲部においては, その 半径方向に内向きの砂粒の移動を生じる. 一方, 本モデ ルの浮遊砂輸送は水深平均流によるものであり， 2 次 流補正は行われていない。 また, 流路の横断勾配に関 しても浮遊砂の浮上量には影響しない. そのため,こ 


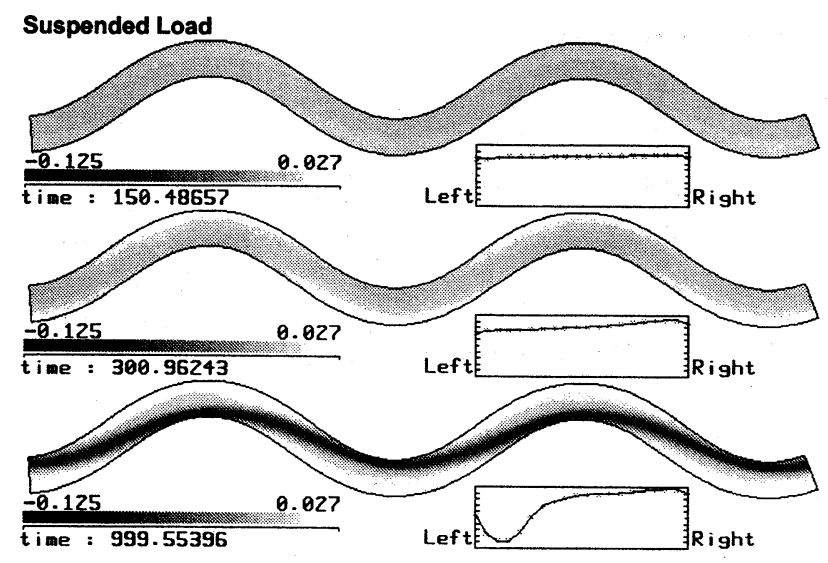

図 9: 河床変動計算 浮遊砂のみ

のような変動をするものと思われる．この点には十分 注意して，本モデルを評価しなければならない，また， 浮遊砂移送に対しての直接的な 2 次流補正は, 今後, 取 り組むべき重要な課題であると言えよう. 次章では, 石 狩川下流域模型実験の再現計算を行い, より詳細に本 モデルの妥当性を検討する.

\section{7.模型実験の詳細と計算条件}

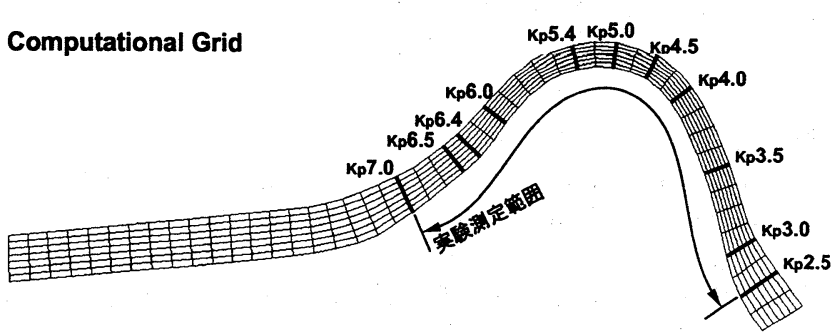

図 10：石狩川模型実験平面図（計算格子）

前章では, Sine-generated Curveにおいての掃流・浮 遊混在条件での検討を行った。本章では浮遊砂が卓越 する条件での検討を行いたい，なぜならば，石狩川や 尻別川のみならず，多くの河川の下流域では土砂の輸 送形態は掃流砂よりも浮遊砂が支配的であり, 河川工 学的な見地からも，浮遊砂を有効に計算するモデルの 発達が非常に重要となっているからである. そこで, 前 述の浮遊砂を含む平面 2 次元一般座標モデルを石狩川 下流域模型実験 (昭和 59 年度, 北海道開発局による) に適用し，再現計算を行う。そして，その妥当性を検討 する. この実験は, 洪水時の流下能力増大を目的とし た「2-Way 水路計画案」を検討する一連の実験であっ た. 本研究ではそのうち, 一方の水路を遮断して行わ れた 1-Way 実験の再現を試みた。

\section{表-1：石狩川模型実験諸条件}

\begin{tabular}{|c||c|}
\hline 流量 & $297(\mathrm{l} / \mathrm{s})$ \\
\hline 初期河床勾配 & $1 / 6950$ \\
\hline 河床材料粒径 & $0.16(\mathrm{~mm})$ \\
\hline 河床材料比重 & 1.436 \\
\hline 下流端水深 & $14.8(\mathrm{~cm})$ \\
\hline 測定区間平均水路幅 & $6.10(\mathrm{~m})$ \\
\hline 通水時間 & 10 時間 \\
\hline 縮尺 & $1 / 50$ \\
\hline
\end{tabular}

実験水路は図-10に示すように, 中間部に川幅の変 化および湾曲部を有している．河床材料は浮遊砂の卓
越を容易にするため比重の小さい石炭紛を使用し，初 期河床を一定の縦断勾配，水平の横断勾配として，10 時間一定流量を通水している。. また，図-10に示した 範囲の上流には, 約 $60 \mathrm{~m}$ の直線水路を助走区間として 配置し，2 時間ごとに助走区間の河床にその低下量分だ けの河床材料が補給されている. 通水後には Kp2.5〜 Kp7.0 の範囲で 11 横断面での河床高が測定されている. なお,この区間以外は顕著な河床変動は見られなかっ た．諸々の水理量等は表-1に示寸通りである.

また再現計算では，掃流砂のみの場合や浮遊砂のみ の場合の計算を行い，湾曲部における河床変動にそれ ぞれの流砂量式がどのように影響を及ぼしているかを 検討した. 各水理量, 地形等については, 模型実験と 同条件（表-1）で計算した。また，河床の横断形状を 決定する重要なパラメータの一つに (21) 式中の摩擦係 数 $\mu_{s} \mu_{k}$ がある. 今回は一般的な值である $\mu_{s} \mu_{k}=0.5$ をそれぞれ用いて計算した。

\section{表-2：計算条件分類}

\begin{tabular}{|c||c|c|c|}
\hline Case & 浮遊砂 & 墇流砂 & 摩摽係数 \\
\hline \hline Case1-3 & $\bigcirc$ & $\bigcirc$ & 0.5 \\
\hline Case2-3 & $\times$ & $\bigcirc$ & 0.5 \\
\hline Case3-1 & $\bigcirc$ & $\times$ & - \\
\hline
\end{tabular}

\section{8. 再現計算（石狩川模型実験）の結果}

図-11に 10 時間通水後の計算結果の河床コンター図を 示す. 上から Case1-3 (掃流砂・浮遊砂の場合), Case23 (浮遊砂のみを計算する場合), Case3-1（掃流砂のみ を計算する場合）である.摩擦係数の值はいずれも 0.5 である. そして, 図-12 に模型実験の結果を示す，それ ぞれ，10 時間通水後の初期河床からの変動量を表して いる. 図-11 を見てみると, 模型実験が浮遊砂が卓越す る条件を想定しているためか，やはり掃流砂のみを計 算する Case3-1 では，ほとんど河床は変化していない． その一方で浮遊砂を計算する Case1-3 と Case2-3 は上 流部湾曲部入り口では内岸側に深掘れが生じており,こ れが曲頂部付近で水路の中心部, 湾曲部後半から下流 直線部にかけて外側へと移動する．ただし，深掘れが 移動する位置は Case-1-3, Case-2-3, 実験結果のうち, Case2-3 が最も上流側に位置し，実験結果が最も下流側 に位置する．Case-1-3については両者の中間あたりに 位置する。この結果が意味するところはそれぞれの流 砂量式が, 流れの位相遅れを表現できているかいない かによるものと思われる。つまり, Case2-3（浮遊砂の み）では 2 次流や河床横断形状に関わる補正が全くな いので，位相遅れは全く表現できないが，Case1-3（掃 流砂・浮遊砂）については, 掃流砂について流路横断 方向に流砂量を想定していることによって 2 次流の影 響が加味されている.さらに, Case1-3よりも Case2-3 の方が深掘れ量は全体的に大きい。これは掃流砂を計 算する時に横断勾配を考慮するが，浮遊砂がある程度 以上哚掘れを生じさせると, それ以上侵食が進まない 方向に掃流砂を発生させて断面形状を規定しているも のと思われる.ここで, 非常に面白いのは模型実験が 浮遊砂が卓越する条件を想定し，実際に掃流砂のみの 計算（Case3-1） ではほとんど河床形状に変化がないの にもかかわらず，浮遊砂・掃流砂いずれも計算する場合 （Case1-3）には河床形状に掃流砂の影響が色濃く反映 されているということである.つまりこれは，浮遊砂 卓越の条件であっても掃流砂も同時に計算する必要が あるか，もしくは浮遊砂にも掃流砂同様，2次流や斜面 
の横断勾配を考慮する必要性があることを示唆してい る. 以上の結果は単湾曲部における河床変動であるた め, 必ずしも Sine-generated Curve の計算結果と対応 しているわけではないが，両者に共通して言えること は浮遊砂のみの計算では流砂量の横断方向の評価が不 十分であり，掃流砂をも含めて計算することによって， より良好な結果が得られるということである.

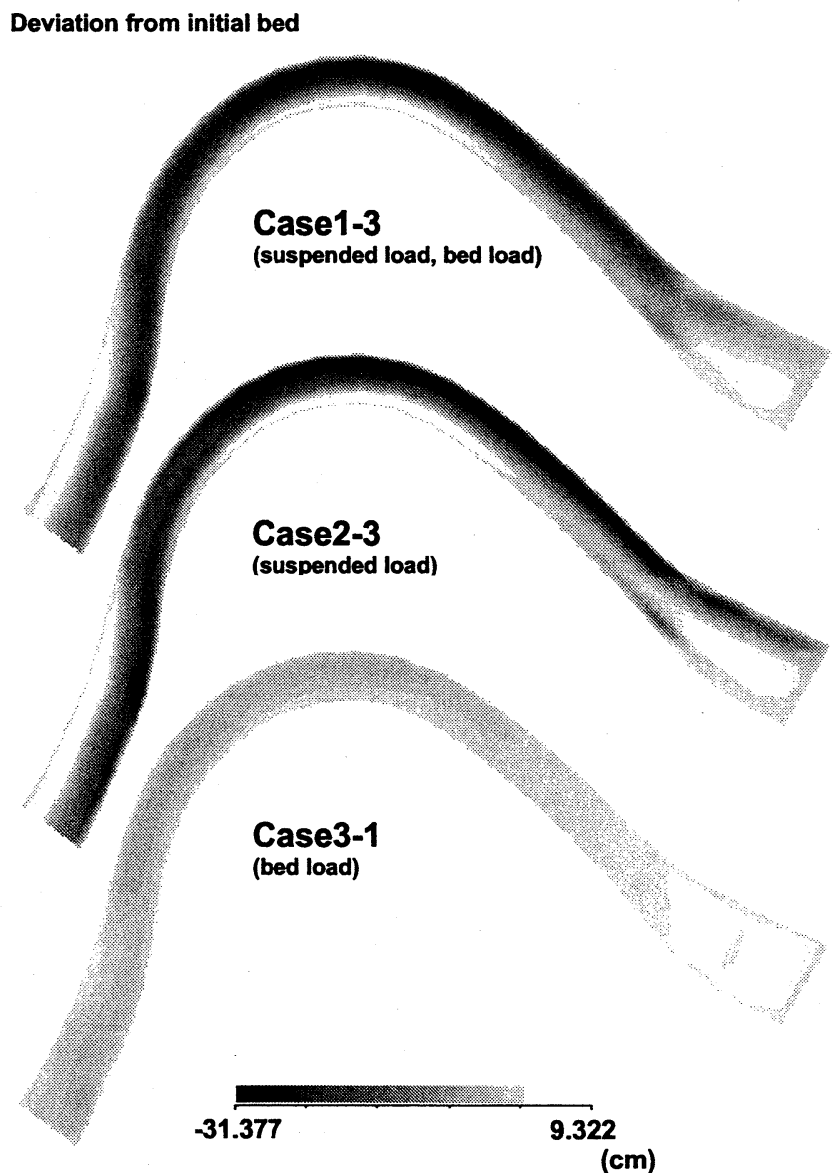

図 11: 河床変動計算 Case1-3, Case2-3, Case3-1

\section{9.おわりに}

本研究は浮遊砂を含む平面 2 次元一般座標河床変動 モデルの構築とその検証を目的とした. Sine-generated Curve の蛇行水路での試行計算や石狩川下流域模型実 験の再現計算を通して本研究の計算モデルの妥当性を 検証した. その結果, 浮遊砂の卓越するような条件に おいてもある程度の再現性が確認されたが，それには 掃流砂をも同時に計算しなければ有効な結果が得られ ないことが示された。すなわち浮遊砂の浮上や浮遊砂 濃度の移送には 2 次流や斜面の横断勾配などといった 影響が考慮されておらず，浮遊砂のみの計算では正確 な河床変動は表現できない。一方, 掃流砂量式でのそ れらの補正が, 浮遊砂が卓越する条件においても補助 的に㗢くことが分かった，そのメカニズムはおおよそ 次のように要約されよう. すなわち, 浮遊砂によって洗 掘が生じ, ある程度, 河床形状が変化すると河床せん 断力が変化し, 掃流砂が生じる。 そしてその掃流砂量 を評価する式には 2 次流や斜面勾配の影響を考慮する 項が内包されており, 結果として, それらの影響を加 味した河床形状を形成すると思われる。しかしながら， この効果も実験結果と十分合致するまでの結果を得る

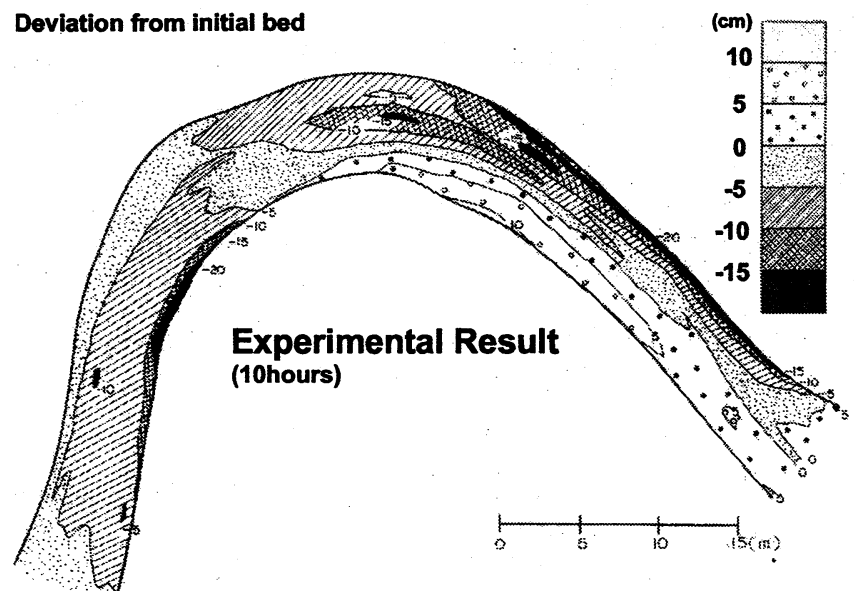

図 12: 石狩川模型実験結果

ことはできず，これだけでは不十分であると言える.す なわち, 今後の課題としては浮遊砂の浮上や移送に対 しても，2 次流の補正や斜面の影響を加味したり，ある いは，流れの位相遅れという点に関して，流れの計算 精度そのもののさらなる向上が求められよう. 湾曲部 における 2 次流などの 3 次元的な流れを平面 2 次元上 で表現しようとする以上，このあたりの議論は避けて は通れず, 最も重要な問題である.

\section{参考文献}

1)Itakura,T. and Kishi,T. : Open chennel flow with sus -pended sediments.Proc. of ASCE, HY8, pp.1325$1343,1980$.

2) 芦田和男, 道上正規 : 移動床流れの抵抗と掃流砂量に 関する基礎的研究, 土木学会論文報告集, 第 206 号, pp.59-69, 1972

3) 渡邊明英, 福岡捷二, 安竹悠, 川口広司: 河道湾曲部 における河床変動を抑制する樹木群水制の配置方法, 河川技術論文集, pp.285-290，2001.

4) 長田信寿, 細田尚, 村本嘉雄, Md. Munsur Rahman : 移動一般座標系による側岸侵食を伴う河道変動の数值 解析, 水工学論文集, pp.927-932，1996.

5) 長谷川和義 : 沖積蛇行の平面および河床形状と流れに 関寸る水理学的研究, 北海道大学博士論文, pp.1-183, 1984.

6) 星清, 清水康行ら: 現場のための水理学, 北海道開発 局土木試験所（現開発土木研究所）河川研究室編, 1988.

7)Engelund,F. : Flow and Bed Topography in Channel Bend, Jour. of Hydr. Div., ASCE, Vol.100.

HY11, pp1631-1648, 1974.

8) 清水康行 : 蛇行河川における 3 次元流れと掃流砂 - 浮 遊砂を考慮した河床変動の計算, 北海道開発局開発土 木研究所 河川研究室編, 1988.

9) 星清ら：河川に関する調査・試験 - 研究報告書, 北海 道開発局開発土木研究所 河川研究室編, 1988.

(2002. 9. 30受付) 